\title{
WORKPLACE INCIVILITY, SELF-EFFICACY, AND TURNOVER INTENTION RELATIONSHIP MODEL: A MULTI-GROUP ANALYSIS
}

\author{
Riadi Sukisno Selamat ${ }^{1 *}$, Hendryadi ${ }^{2}$, Tricahyadinata Irsan $^{1}$ \\ ${ }^{1}$ University of Mulawarman, Indonesia \\ ${ }^{2}$ Sekolah Tinggi Ilmu Ekonomi Indonesia, Indonesia \\ *E-mail: sukisno.selamet.riadi@feb.unmul.ac.id
}

\begin{abstract}
The purpose of this paper is to compare the relationship between workplace incivility, selfefficacy, and employees' turnover intentions based on gender in Indonesian work settings. The mediating roles of self-efficacy on the relationships between workplace incivility and turnover intention were also investigated. Data were collected randomly from 300 employees at various companies in Jakarta via the self-assessment questionnaires and, thereafter, partial least square multi-group analysis (PLS-MGA) was performed to analyze the data. According to result, workplace incivility had significant negative effects on self-efficacy, and a positive effect on turnover intention. Self-efficacy had significant positive effects on turnover intention, and confirmed the mediating role of self-efficacy between workplace incivilityturnover intention relationship. Coefficient analysis shows the strength of the relationship between variables varied by gender. Implications for organizations are discussed.
\end{abstract}

\section{KEY WORDS}

Workplace incivility, self-efficacy, turnover intention, PLS-MGA.

Throughout the last two decades, workplace incivility emerged as a significant construct in management literature (Rahim \& Cosby, 2016). Workplace incivility is a form of behavior such as making condescending statements, making veiled threats, expressing insults in the form of words and body language, spreading gossips, ignoring co-workers' requests, or vice versa, which shows disrespect for others in the workplace (Holm, Torkelson, \& Backström, 2015; Reich \& Hershcovis, 2015). Starting in 1998, one study found that nearly half of the employees surveyed reportedly being treated at least once a week, and then increased dramatically in 2005 and 2011 (Porath et al., 2015). Pearson et al. (2000) conducted an extensive survey and found that most employees have witnessed more than one act of incivility at their workplace. in 2009 , their survey found that 96 percent of surveyed employees indicated experiencing incivility, while 99 percent indicated witnessing incivility (Pearson \& Porath, 2009). In 2011, Porath and Pearson (2012) reported that a shocking 98 percent of their respondents experienced uncivil behavior at their workplace. Further, more than 60 percent of those employees admitted that the experiences diminished their commitment towards their organizations.

Workplace incivility consists of discourteous interactions between employees that violate norms of mutual respect and unethical behaviors (Cortina, Magley, Williams, \& Langhout, 2001; Hanrahan \& Leiter, 2014). The most cited definition in the literatures from Andersson and Pearson's (1999) as "low intensity behavior with ambiguous intent to harm the target, in violation of workplace norms for mutual respect; uncivil behaviors are characteristically rude and discourteous, displaying a lack of regard for others" (p. 457). Empirical research suggests that employees targeted with uncivil behavior show greater jobstress, cognitive distraction, psychological distress, as well as lower job satisfaction and creativity, higher turnover intentions, reduced work quality and effort (Cortina \& Magley, 2009); reduced work quality and effort (Pearson \& Porath, 2009). Recently, some empirical studies found a positive relationship between incivility with counterproductive work behavior such as abuse, production deviations, sabotage, theft, and withdrawal (Bibi et al. 2013). Other studies report that incivility is associated with higher absenteeism, levels of anger, fear, and sadness at work (Porath and Pearson, 2012), job dissatisfaction, and fatigue 
(Welbourne et al., 2015; Kim et al., 2013; Rahim and Cosby, 2016), and turnover intention (Rahim \& Cosby, 2016; Sharma \& Singh, 2016). Incivility is also directly related to productivity (Lewis \& Melecha, 2011; Rahim and Cosby, 2016).

Although several studies have indicated a range of negative outcomes associated with workplace incivility, some limitations are still found. First, few studies have examined the impact of incivility on personality factors, such as self-efficacy. Fida et al. (2016) found that occupational coping self-efficacy (ROC-CE) associated with incivility from coworkers, supervisors, and physician. Employees with higher ROC-CE will perceive less frequent workplace incivility. Self-efficacy is an individual's ability to consider himself/herself capable of performing a particular task (Bandura, 1997), and can be influenced by the organizational environment such as perceived-organizational support (Islam and Ahmed, 2017). In line with this assumption, the current study examines incivility as an antecedent of self-efficacy. Second, very few studies about workplace incivility and turnover intentions have been conducted in Asian countries (Sharma \& Singh, 2016). Although some previous studies have examined the direct effect of incivility on turnover intention (Sharma \& Singh, 2016; Rahim \& Cosby, 2015) much less is known regarding the mechanisms through which incivility negatively influences turnover intention.

The primary objectives of the current study were four-fold. First, this study made an attempt to examine the direct effect of workplace incivility on self-efficacy, and that is different from previous studies that examined the effect of self-efficacy on workplace incivility (Fida, Lasinger \& Leiter, 2016). Second, this study examined the mediating role of selfefficacy between workplace incivility-turnover intention. This extends recent research studying the direct effect of incivility on turnover intention (Sharma \& Singh, 2016; Rahim \& Cosby, 2015; Reio \& Trudel, 2013). Third, workplace incivility differs by gender (Welbourne et al. 2015; Miner \& Eischeid, 2012). For this reason, the third objective of this study is to examine the varied relationship between workplace incivility, self-efficacy and turnover intention by gender. Finally, workplace incivility is an inevitable concern for every type of organization, irrespective of its location in the world (Sharma \& Singh, 2016). While the incidence and impact of incivility are receiving a lot of attention in the U.S. and Europe, it is not much discussed and studied in Asia (Yeung \& Griffin, 2008), especially in Indonesia. This study can provide new empirical evidence, and contribute to covering the previous research gap. From practical content, this study can be useful information for managers in Indonesia to be able to manage deviant behavior in the workplace more effectively.

\section{LITERATURE REVIEW}

The social capital theory is a framework for this research, where positive change occurs when social relations in the community are effective and work well. This effective and goodness contains trust, reciprocity, collaboration, and cooperation, and interaction between members. To succeed, employees must maintain politeness to build social capital and strengthen collaboration in the workplace (Kelly \& McAllister, 2013).

Workplace incivility is a form of deviant behavior. Workplace incivility can be interpreted as a low-intensity behavior that has no clear intention to harm, but still violates social norms and hurts the feelings of the targeted employees (Pearson \& Porath, 1999). Incivility is also described as a treatment that is rude, impatient or shows a lack of respect for the dignity of others. As a result, employees who get treatment experience a decrease in commitment over time (Montgomery et al., 2004). Examples of some of these unethical behaviors include not saying thank you, turning eyes on co-workers' suggestions, sending SMS or sending emails during meetings, making derogatory comments, involve expression of hostility, privacy invasion, exclusionary behavior, gossiping and ignoring or insulting coworkers (Pearson \& Porath, 2009).

Workplace incivility and self-efficacy. Self-efficacy consists of an individual's beliefs they are capable to show effective performance (Bandura, 1997). Bandura posited the one factors that influence self-efficacy is physiological and affective states (Kirk et al., 2011). This condition includes a high level of arousal or mood can affect the perception of efficiency, and 
then can lead to higher perceived self-efficacy. In other words, organizational environments such as communication patterns, interactions, and perceived support are related to selfefficacy (Islam \& Ahmed, 2017).

According to the social cognitive theory of Bandura (1997), which states that employees develop their beliefs by their perception. Thus, when they perceive a discourteous interaction that violates norms of mutual respect such as exclusionary from meeting and decision making, and unsupportive environment will decrease individual selfefficacy. The target of uncivil behavior is associated with lessened well-being (Martin \& Hine, 2005), and one of the important aspects of subjective well-being is self-efficacy (Kurtessis et al., 2015). Similarly, Fida et al. (2016) found that occupational coping self-efficacy (ROC-CE) associated with incivility. Based on the theoretical and literature reviews above, we hypothesized that:

$\mathrm{H} 1$ : Workplace incivility is negatively related to self-efficacy.

Workplace incivility, self-efficacy and turnover intention. Turnover means that left the current job, or the employees leaving an organization voluntarily. An employee's decision to leave an organization is costly for an organization, especially the inevitable economic losses were for replacement, selection, and training costs. Literature is clear about the importance of workplace incivility, as it influences turnover intention (Rahim \& Cosby, 2016; Sharma \& Singh, 2016; Cortina et al., 2013). Using undergraduate business administration students in the United States, Rahim and Cosby (2016) found that workplace incivility was positively associated with turnover intention. In different sectors, Sharma and Singh (2016) found that workplace incivility may lead to significant levels of turnover intention from the Indian restaurant industry. Cortina et al. (2013) also linked workplace incivility with turnover intentions among employees. Hence, on the basis of the studies above, a second hypothesis has been proposed:

$\mathrm{H} 2$ : workplace incivility is positively related to turnover intention.

Similarly, we have assumed self-efficacy incivility acts as a significant predictor of turnover intentions amongst employees. Self-efficacy is a most strongly predict teachers' psychological well-being, physical health, and quitting intentions (Wang, Hall \& Rahimi, 2015). Fallatah et al. (2017) in their study found that self-efficacy has a relationship with turnover intention, and simultaneously mediates the authentic relationship of leadership turnover intention. Another study conducted by Van Waeyenberg et al. (2015) found that the relationship between the quality of feedback - turnover intention was fully mediated by home nurses' self-efficacy. Based on the above literature, two hypotheses are proposed:

$\mathrm{H} 2$ : self-efficacy is negatively related to turnover intention.

H3: self-efficacy mediates the relationship between workplace incivility and turnover intentions.

\section{METHODS OF RESEARCH}

Sampling Procedure. The data for the study were collected from 300 employees from 15 companies operating in the Jakarta area. The majority of them were male $(52 \%)$ and belonged to the 21 - 30 years age group (83\%). Approximately $67 \%$ of the participants' highest educational attainment was a senior high school, $15 \%$ had some college, and $18 \%$ reported earning a bachelor's and master degree. Finally, most (65\%) the marital status of participants is single (unmarried).

Measurements. Workplace incivility. This study uses a seven-item scale developed by Cortina et al. (2001) to measure the extent to which employees have experienced workplace incivility in the past year. The items were rated on a five-point Likert scale (never $=1$, rarely $=2$, sometimes $=3$, often $=4$, most of the time $=5$ ). An example item is "How often in the past year has incivility occurred as acting discourteously". This scale has been tested and has Cronbach a internal consistency of 0.87 (Chen et al., 2010); and 0.89 (Rahim \& Cosby, 2016). In the present study, the internal consistency of this scale was 0.84 .

Self-efficiency is measured through a five-item scale from Jones (1986). The sample item of this scale is, "My job is well within the scope of my abilities." Using the same scale 
Islam and Ahmed (2018) yielded its Cronbach a internal consistency as 0.88 . However, the value of internal consistency of this study was 0.87 .

Turnover intention. Three turnover intention subscale items from the Michigan Organizational Assessment Scale (Seashore et al., 1982) are used to measure respondents' turnover intentions. Sample items for the scale are, "i am actively looking for a new job," and "I often think of stopping". Responses range from 1 (strongly disagree) to 5 (strongly agree). The possible score range is 3 to 15. A higher score on the scale shows a higher level of intention to quit. This scale has been shown to have adequate reliability and validity $(\alpha=$ 0.91, Karim et al., 2015). In the present study, the value of internal consistency of this study was 0.79 .

Statistical analysis. The first part of the analysis was designed to test the psychometric properties of the measures of incivility, work engagement, and turnover intention (measurement model). The second part of the analysis was designed to test the hypotheses (structural model). Partial least square structural equation modeling (PLS-SEM) with a multigroup analysis approach is used to test the model. PLS-SEM was adopted because of its advantages over covariance-based modeling, non-normal data, and more appropriate where theory is less developed/ exploratory research (Hair et al., 2011; 2014). Data analysis was performed using SmartPLS 3.0 software (Ringle et al., 2012).

\section{RESULTS AND DISCUSSION}

Descriptive Analysis. The first analysis begins with descriptive statistics that show the means and standard deviations for the study variables.

Table 1 - Descriptive Statistics

\begin{tabular}{|c|c|c|c|c|}
\hline $\mathrm{n} / \mathrm{n}$ & Gender & $\mathrm{N}$ & Mean & Std. Deviation \\
\hline \multirow{2}{*}{ WIC } & Male & 156 & 2.13 & .77 \\
\cline { 2 - 5 } & Female & 144 & 1.93 & .70 \\
\hline \multirow{2}{*}{$\mathrm{SE}$} & Male & 156 & 3.69 & .81 \\
\cline { 2 - 5 } & Female & 144 & 3.73 & .71 \\
\hline \multirow{2}{*}{$\mathrm{TI}$} & Male & 156 & 2.32 & .98 \\
\cline { 2 - 5 } & Female & 144 & 2.48 & 1.02 \\
\hline
\end{tabular}

Note: $W I C=$ workplace incivility, $S E=$ self-efficacy; $T I=$ turnover intention .

Table 1 shows the mean score of workplace incivility, self-efficacy, and turnover intention for males group is slightly higher than females. Unexpectedly, males are perceived as having more high levels of efficiency than females. These data are different from previous studies which state that women are more likely to be targets of incivility behaviors (Welbourne et al. 2015; Miner \& Eischeid, 2012; Cortina, 2008).

Structural Equations Model. In this study, the measurement and model of the models were measured in a single step, and the presentation of the results of the recommendations of Chin (2010) and Hair et al. (2011; 2014). Accordingly, measurement model (outer model) testing was performed first, followed by the evaluation of significance among parameters (inner model).

Measurement model testing (outer model). Study measures were next examined for internal consistency, construct validity (convergent validity and discriminate validity) as prescribed by Hair et al. (2014). The first stage, internal consistency was evaluated using Cronbach's a coefficient and construct reliability (CR). Cronbach's alphas as indicators measure reliability for fist order measurement model were above $0.70(\mathrm{WI}=0.84$; SE $=0.87$; $\mathrm{TI}=0.79)$. Futhermore, all composite reliability $(\mathrm{CR})$ above $0.70(\mathrm{WI}=0.88 ; \mathrm{SE}=0.90 ; \mathrm{TI}=$ 0.88), this considered satisfactory for internal consistency (Hair et al., 2011). It can be concluded that the measurement model has fulfilled all reliability requirements as recommended by Hair et al. (2014) and Chin (2010).

Construct validity was assessed by examining convergent validity and discriminant validity. Convergent validity is assessed through factor loadings $(\lambda)$ and average variance 
extracted (AVE). Fornel and Larcker (1981) recommended cut-off value for AVE is 0.50, and loading above 0.70. As shown in Table 2, all indicator loadings are significant and exceed 0.7 , and all AVE are greater than 0.50, this considered satisfactory (Hair et al., 2011). This result indicates that a set of indicators represents one and the same underlying construct (Henseler et al., 2009).

Table 2 - Scale Items and Evaluation of The Measurement Model

\begin{tabular}{|c|c|c|c|c|c|c|}
\hline Indicator & Loading & std.dev & p-value & Cronbach's $\alpha$ & CR & AVE \\
\hline Workplace incivility (WIC) & & & & 0.84 & 0.88 & 0.52 \\
\hline WIC1 & 0.71 & 0.04 & 0.00 & & & \\
\hline WIC2 & 0.65 & 0.05 & 0.00 & & & \\
\hline WIC3 & 0.78 & 0.03 & 0.00 & & & \\
\hline WIC4 & 0.77 & 0.03 & 0.00 & & & \\
\hline WIC5 & 0.73 & 0.03 & 0.00 & & & \\
\hline WIC6 & 0.71 & 0.04 & 0.00 & & & \\
\hline WIC7 & 0.68 & 0.04 & 0.00 & & & \\
\hline Self-efficacy (SE) & & & & 0.87 & 0.64 \\
\hline SE1 & 0.80 & 0.04 & 0.00 & & & \\
\hline SE2 & 0.88 & 0.02 & 0.00 & & & \\
\hline SE3 & 0.82 & 0.05 & 0.00 & & & \\
\hline SE4 & 0.71 & 0.07 & 0.00 & & & \\
\hline SE5 & 0.78 & 0.04 & 0.00 & & 0.88 & 0.71 \\
\hline Turnover intention (TI) & & & & & & \\
\hline TI1 & 0.84 & 0.02 & 0.00 & & & \\
\hline TI2 & 0.86 & 0.02 & 0.00 & & & \\
\hline TI3 & 0.82 & 0.03 & 0.00 & & & \\
\hline
\end{tabular}

Discriminant validity examines to what extent a given construct differs from other constructs, and considered well when the loadings of the indicator variables on their latent variable is higher than the other latent variable (Hair et al., 2011). As shown in Table 3, for example, WIC1, WIC2 and WIC3 indicators have a greater loading factor on workplace incivility than other constructs. So it can be stated that a construct has more variance with its indicators than with other constructs. This shows that the measurement model meets discriminant validity.

Table 3 - Discriminant Validity: Cross-Loading

\begin{tabular}{|c|c|c|c|}
\hline Indicator/Construct & Incivility & Self-Efficacy & Turnover \\
\hline WIC1 & 0.71 & -0.05 & 0.27 \\
\hline WIC2 & 0.65 & -0.13 & 0.25 \\
\hline WIC3 & 0.78 & -0.17 & 0.34 \\
\hline WIC4 & 0.77 & -0.16 & 0.25 \\
\hline WIC5 & 0.73 & -0.18 & 0.25 \\
\hline WIC6 & 0.71 & -0.23 & 0.22 \\
\hline WIC7 & 0.68 & -0.22 & 0.28 \\
\hline SE1 & -0.22 & 0.80 & -0.22 \\
\hline SE2 & -0.29 & 0.88 & -0.27 \\
\hline SE3 & -0.11 & 0.82 & -0.13 \\
\hline SE4 & -0.10 & 0.71 & -0.09 \\
\hline SE5 & -0.09 & 0.78 & -0.16 \\
\hline TI1 & 0.33 & -0.23 & 0.84 \\
\hline TI2 & 0.34 & -0.20 & 0.86 \\
\hline TI3 & 0.26 & -0.19 & 0.82 \\
\hline
\end{tabular}

Another parameter recommended by Fornell-Larcker (in Hair et al., 2011) is comparing AVE with correlation between latent variables. The measurement model is stated to have good discriminant validity if the correlations among latent variables should be lower than the square of the AVE. As shown in Table 4, the square of the AVE for all latent variables was greater than the correlation among variables. It can thus be concluded that the scales used in this study have sufficient construct validity. 
Table 4 - Discriminant Validity: Fornell-Larcker Criterion

\begin{tabular}{|c|c|c|c|}
\hline $\mathrm{n} / \mathrm{n}$ & Incivility & Self-Efficacy & Turnover \\
\hline Incivility & 0.72 & & 0.80 \\
\hline Self-Efficacy & -0.24 & -0.25 & 0.84 \\
\hline Turnover & 0.37 & & \\
\hline
\end{tabular}

Note: The square root of the AVEs are italic bold.

Structural model testing (Inner model). Having determined the measurement model, the evaluation criteria the structural model as suggested by (Hair et al., 2014). The basic structural model metrics of $R^{2}$ and $Q^{2}$ as an initial evaluation, followed by path coefficients, and significance will be reported.

The $R^{2}$ of dependent variables provides the amount of variance that is explained by the model. Chin (1998) established the following threshold values for $\mathrm{R}^{2}$ : 0.67 "substantial"; 0.33 "moderate" and 0.19 "weak" predictive value. The $\mathrm{R}^{2}$ values obtained for this model show that the both variables (self-efficacy and turnover intention) has a weak predictive power $\left(R^{2}\right.$ $=0.05$ and $\left.R^{2}=0.16\right) . Q^{2}$ indicates predictive relevance. Evaluation of the model using blindfolding to obtain cross-validated redundancy measures for each construct. The $\mathrm{Q}^{2}$ values of larger than zero indicate that the exogenous constructs have predictive relevance for the endogenous construct (Hair et al., 2011). The results of the study show that the $Q^{2}$ value for self-efficacy is 0.03 , and turnover intention is 0.11 . This results indicating that workplace incivility is a lack of predictive relevance for self-efficacy and turnover intention.

The next step, bootstrapping is used to assess the path coefficient significance. The minimum number of bootstrap samples is 5,000 as recommended by Hair et al. (2014). To conduct group comparisons, structural model testing multi-group analysis (PLS MGA) is used. Table 5 displays the $p$-value and confidence interval obtained for each path coefficient.

Table 5 - Path Coefficient Results

\begin{tabular}{|c|c|c|c|}
\hline Path & $\begin{array}{c}\text { All Group } \\
\mathrm{N}=300\end{array}$ & $\begin{array}{c}\text { Men } \\
\mathrm{N}=156\end{array}$ & $\begin{array}{l}\text { Women } \\
\mathrm{N}=144\end{array}$ \\
\hline Incivility -> Self-Efficacy & -0.24 & -0.17 & -0.34 \\
\hline Incivility -> Turnover & 0.33 & 0.38 & 0.34 \\
\hline Self-Efficacy -> Turnover & -0.17 & -0.25 & -0.08 \\
\hline Incivility $->$ Self-Efficacy $->$ Turnover & 0.04 & 0.04 & 0.03 \\
\hline
\end{tabular}

Notes: ${ }^{*} p<0.05 ;{ }^{* *} p<0.01$, group $1=$ all samples, group $2=$ men; group $3=$ women.

This paper empirically tests the relationship between workplace incivility (WIC), selfefficacy (SE), and turnover intention (TI) in the Indonesian business sector organizations. Specifically, this paper predicted that WIC has a direct and negative relationship with selfefficacy $(\mathrm{H} 1)$, WIC has a direct and positive relationship with turnover intention $(\mathrm{H} 2)$, selfefficacy has a direct and positive relationship with turnover intention (H3), and self-efficacy will mediate the relationship between WIC and turnover intention $(\mathrm{H} 4)$.

Table 5 presents the results of the structural model analysis. It was predicted that WIC would have a negative relationship with self-efficacy (coefficient $=-0.24, \mathrm{p}$-value 0.00 ), $\mathrm{H} 1$ supported. This result provides support to the first hypothesis of this study. It suggests that when employees perceive high-levels of incivility, such perception can decrease their level of self-efficacy. The link between WIC and self-efficacy is a new finding. There is some evidence relational occupational coping self-efficacy (ROC-CE) to incivility from coworkers, supervisors, and physician (Fida et al., 2016), employees with higher ROC-CE will perceive less frequent workplace incivility, bullying was negatively correlated with overall self-efficacy (Rapp et al., 2015), but we could find a studies linking WIC to self-efficacy, especially WIC as an antecedent of self-efficacy.

The result of the analysis further indicates that the relationship between workplace incivility and self-efficacy showed significantly higher at females group (coefficient $=-0.34, p$ value 0.00 ), as compared to the men (coefficient $=-0.17$, $p$-value 0.00 ). This result is not surprising given the gender of factors affecting self-efficacy, or the perceptions, acceptance, 
and the impact of incivility may differ by gender. This finding is consistent with previous research that indicated physiological and affective states (e.g., disappointing situation, negative mood) can influence the perception of efficacy (Bandura, 1997). Women are more likely to be targets of incivility behavior in the workplace than men (Welbourne et al. 2015; Miner \& Eischeid, 2012; Cortina, 2008). The consequence is the female are more likely to have higher interpersonal problems such as privacy invasion and exclusionary behavior in the workplace.

Workplace incivility played an important role in predicting turnover intention. The results of the analyses indicate that a significant and positive relationship exists between WIC and turnover intention (coefficient $=0.33, \mathrm{p}$ value 0.00 ), confirming $\mathrm{H} 2$. This results support previous evidence the positive impact of workplace incivility on employee turnover (Sharma \& Singh, 2016; Rahim \& Cosby, 2015). Sharma and Singh (2016) found a significant relationship between workplace incivility and turnover intentions of employees in India. Rahim and Cosby, (2015) found that victims of workplace incivility tended to consider voluntarily resigning from the company. Surprisingly, workplace incivility was more strongly related to turnover intention for males groups (coefficient $=0.38, p$ value 0.00 ), compared to female (coefficient $=0.34$, $p$ value 0.00 ).

The results also found an interesting phenomenon, where the perception of workplace incivility in men was higher than women (see Table 1). This finding supports and has differences with previous findings. For example, there are differences in the acceptance of incivility between men and women in line with Welbourne et al. (2015); Miner and Eischeid, (2012); and Cortina, (2008). However, previous research stated that women are more likely to be victims of incivility in the workplace than men. It would safe to say that workplace incivility intensifies feelings of turnover intention amongst employees and when this perception increased, it leads to employees voluntarily considering quitting their jobs. This effect is generally applicable to men and women, and there is no difference in response turnover intention based on gender. This study suggest, both men and women who have experience of being victims of workplace incivility have the same tendency to leave the organization. These results add to this knowledge by demonstrating the positive effect of working in social work settings in which employees treat each other respectfully and refrain from uncivil behaviors in their day to day work.

The results was also found that SE would negatively predict turnover intention (coefficient $=-0.17, \mathrm{p}$ value 0.00 ), H3 supported. This finding is consistent with previous studies (Fallatah et al., 2017; Van Waeyenberg et al., 2015; Wang et al., 2015). However, this relationship was not significant for womens group. The nonsignificant effect between SE and turnover intention for women's groups shows that the level of self-efficacy is not a factor that influences women to decide to resign from their jobs. This extends recent research studying the direct effect of SE on turnover intention (Fallatah et al., 20015; Van Waeyenberg et al., 2015) that gender has an important role in the relationship.

Finally, the results suggest that WIC can reduce employee self-efficacy, which in turn increase turnover intention in the workplace. This relationship between WIC and turnover intention was partially mediated by employee self-efficacy. The significant relationship between the factors (WIC - self-efficacy - turnover intention) is an important finding that has not been empirically determined previously, particularly in the workplace incivility literature.

Theoretical and practical implications. The study contributed to the existing knowledge on workplace incivility in a number of ways. First, this study made an attempt to examine the direct effect of workplace incivility on self-efficacy, and that is different from previous studies that examined the effect of self-efficacy on workplace incivility (Fida et al., 2016). Second, this study examined the mediating role of self-efficacy between workplace incivility-turnover intention. The significant relationship between the factors (workplace incivility - self-efficacy - turnover intention) is an important finding that has not been empirically determined previously, particularly in the workplace incivility literature. This extends recent research studying the direct effect of WIC on turnover intention (Sharma \& Singh, 2016; Rahim \& Cosby, 2015) and the effect of self-efficacy on turnover intention (Fallatah et al., 20015; Van 
Waeyenberg et al., 2015; Wang et al., 2015). Finally, the relationship between workplace incivility, self-efficacy, and turnover intention was found varied by gender.

From the findings highlighted earlier, there are some key implications for organizations to consider. This study suggests that managers must attend to workplace conditions for decrease employee turnover intention, such as workplace incivility, and circumstances that lead to a decrease in the self-efficacy. Our findings suggest that workplace incivility plays a key role in self-efficacy and employee turnover intention. This finding also confirms that all employees, both men, and women, have the right to be treated with respect and fairness in the workplace. In addition, when an organization is considered implicitly or explicitly tolerating disrespectful behavior, this can be a culture which will subsequently have a negative impact on the organization and individuals. Disrespectful actions that occur if not responded properly can become habits, repeat and create a hostile working environment, which can lead to retaliatory actions from the victim (Andersson and Pearson, 1999). Such situations will lead to extreme forms of counterproductive work behavior, which can lead to aggression or violence.

Therefore, it is important for top management to recognize the existence of impoliteness in the workplace and stop it as early as possible. For example, to encourage a work environment that prioritizes mutual respect, organizations must encourage a cultural value that changes and prohibits all forms of disrespectful behavior among employees, and between leaders and subordinates. At the level manager or supervisor it is recommended to regularly attend communication and leadership training to improve their communication skills to interact with employees.

Limitations and future directions. There are a number of limitations in this study. First, the data of this study were collected from business sector organizations in Indonesia using convenience sampling, which could limitize the generalizability of the study. Therefore, it is suggested to the future researcher to replicate the study in various sectors using random sampling, as employees perceptions vary in different cultures (Islam and Ahmed, 2018). Second, the majority of respondents in this study consisted of employees who were young (less than 30 years old), and single (unmarried), so they may not represent values and perceptions for senior employees (over 35 years). Future research is recommended to use more varied samples by adding a percentage of employees over 35 years old, other demographic factors, such as education level and tenure etc., could also affect the prevalence of incivility in workplaces and hence such factors also need to be considered. Finally, the cross-sectional nature of the original study precludes strong claims of causal effects. The study should be replicated using more representative sample to further validate the model. A longitudinal study to examine changes over time would be valuable to test the causality.

\section{CONCLUSION}

The issue of workplace incivility has been a scarcity in Asia, especially in Indonesia. The current study is thus a significant attempt to examine the relationship of this issue with self-efficacy and turnover intention on the Indonesian business sector. In other words, a high level of workplace incivility will reduce self-efficacy and increase employee intention to leave. Nevertheless, the findings suggest that the negative effect of workplace incivility on selfefficacy was only significant in all samples and groups of women, not for men. However, for turnover intention, the effect of workplace incivility was found to be higher for males group. Self-efficacy can reduce turnover intention, and at the same time act as a mediator of workplace incivility - turnover intention relationships. Comparison between groups showed that the effect of self-efficacy on turnover intention was higher in the males group. Finally, workplace incivility is an inevitable concern for every type of organization, irrespective of its location in the world. This study should recommend to concerned practitioners and researchers that they ought to take time as well as actions to inhibit incivility. Every effort must be made by management to create work conditions that prevent workplace incivility before it disturbs both employee and organizational effectiveness. 


\section{REFERENCES}

1. Andersson, L. M. and Pearson, C. M. (1999), Tit for tat? the spiralling effect of incivility in the workplace, Academy of Management Review, 24, pp. 452-71.

2. Bandura, A. (1997), Self-Efficacy in Changing Societies, Cambridge Univer-sity Press, New York, NY.

3. Bibi, Z., Karim, J. and Din, S. (2013), Workplace incivility and counterproductive work behavior: moderating role of emotional intelligence, Pakistan Journal of Psychological Research, 28(2), 317-334.

4. Chen, Y., Ferris, D. L., Kwan, H. K., Yan, M., Zhou, M., \& Hong, Y. (2013). Self-love's lost labor: A self-enhancement model of workplace incivility. Academy of Management Journal, 56(4), 1199-1219.

5. Chin, W. W. (2010). How to write up and report PLS analyses. In Handbook of partial least squares (pp. 655-690). Springer, Berlin, Heidelberg.

6. Cortina, L. M., Kabat-Farr, D., Leskinen, E. A., Huerta, M., \& Magley, V. J. (2013). Selective incivility as modern discrimination in organizations: Evidence and impact. Journal of Management, 39(6), 1579-1605.

7. Cortina, L.M., Magley, V.J., Williams, J.H. and Langhout, R.D. (2001), Incivility in the workplace:incidence and impact, Journal of Occupational Health Psychology, 6(1), 64-80

8. Cortina, L.M. (2008), Unseen justice: incivility as modern discrimination in organizations, Academy of Management Review, 33(1), 55-75.

9. Cortina, L. M. and Magley, V. J. (2009), Patterns and profiles of response to incivility in the workplace, Journal of Occupational Health Psychology, 14, 272-88.

10. Cortina, L. M., Kabat-Farr, D., Leskinen, E. A., Huerta, M., \& Magley, V. J. (2013). Selective incivility as modern discrimination in organizations: Evidence and impact. Journal of Management, 39(6), 1579-1605.

11. Fallatah, F., Laschinger, H. K., \& Read, E. A. (2017). The effects of authentic leadership, organizational identification, and occupational coping self-efficacy on new graduate nurses' job turnover intentions in Canada. Nursing outlook, 65(2), 172-183.

12. Fida, R., Laschinger, H. K. S., \& Leiter, M. P. (2018). The protective role of self-efficacy against workplace incivility and burnout in nursing: A time-lagged study. Health care management review, 43(1), 21-29.

13. Hair, J. F, Black, WC, Babin, BJ, Anderson RE, \& Tatham RL, (2006). Multivariate Data Analisys (Sixth Edition). Upper Saddle River, New Jersey, Prentice Hall, Inc

14. Hair, J. F., Ringle, C. M., \& Sarstedt, M. (2011). PLS-SEM: Indeed a silver bullet. Journal of Marketing theory and Practice, 19(2), 139-152.

15. Hair Jr, J.F, Sarstedt, M., Hopkins, L., \& G. Kuppelwieser, V. (2014). Partial least squares structural equation modeling (PLS-SEM) An emerging tool in business research. European Business Review, 26(2), 106-121.

16. Hanrahan, M., \& Leiter, M. P. (2014). Workplace Mistreatment: Recent Developments in Theory, Research, and Interventions. Inc.

17. Holm, K., Torkelson, E., \& Backström, M. (2015). Models of workplace incivility: The relationships to instigated incivility and negative outcomes. BioMed Research International, 11, 1-10.

18. Islam, T., \& Ahmed, I. (2018). Mechanism between perceived organizational support and transfer of training: Explanatory role of self-efficacy and job satisfaction. Management Research Review, 41(3), 296-313.

19. Jones, G. R. (1986). Socialization tactics, self-efficacy, and newcomers' adjustments to organizations. Academy of Management journal, 29(2), 262-279.

20. Karim, J., Bibi, Z., Rehman, S. U., \& Khan, M. S. (2015). Emotional intelligence and perceived work-related outcomes: Mediating role of workplace incivility victimization. Pakistan Journal of Psychological Research, 30(1).

21. Kelly, J., \& McAllister, M. (2013). Lessons students and new graduates could teach: A phenomenological study that reveals insights on the essence of building supportive learning culture through preceptorship. Contemporary Nurse, 4, 170-177. 
22. Kim, S.Y., Kim, J.K. and Park, K.O. (2013), Path analysis for workplace incivility, empowerment, burnout, and organizational commitment of hospital nurses, Journal of Korean Academy of Nursing Administration, 19(5), 555-564.

23. Kirk, B. A., Schutte, N. S., \& Hine, D. W. (2011). The effect of an expressive-writing intervention for employees on emotional self-efficacy, emotional intelligence, affect, and workplace incivility. Journal of Applied Social Psychology, 41(1), 179-195.

24. Kurtessis, J. N., Eisenberger, R., Ford, M. T., Buffardi, L. C., Stewart, K. A., \& Adis, C. S. (2017). Perceived organizational support: A meta-analytic evaluation of organizational support theory. Journal of Management, 43(6), 1854-1884.

25. Lewis, P. S., \& Malecha, A. (2011). The impact of workplace incivility on the work environment, manager skill, and productivity. Journal of Nursing Administration, 41(1), 41-47.

26. Lim, S., Cortina, L. M., \& Magley, V. J. (2008). Personal and workgroup incivility: Impact on work and health outcomes. Journal of Applied Psychology, 93: 95-107.

27. Martin, R. J., \& Hine, D. W. (2005). Development and validation of the Uncivil Workplace Behavior Questionnaire. Journal of Occupational Health Psychology, 10, 477-490.

28. Miner, K. N., Settles, I. H., Pratt!Hayatt, J. S. and Brady, C. C. (2012), Experiencing incivility in organizations: The buffering effects of emotional and organizational support, Journal of Applied Psychology, 42, 340-72.

29. Miner, K. N., \& Eischeid, A. (2012). Observing incivility toward coworkers and negative emotions: Do gender of the target and observer matter? Sex Roles, 66(7-8), 492-505.

30. Montgomery, K., Kane, K. and Vance, C.M. (2004), Accounting for differences in norms of respect: a study of assessments of incivility through the lenses of race and gender, Group \& Organization Management, 29(2), 248-268.

31. Pearson, C. M., Andersson, L. M. and Porath C. L. (2000), Assessing and attacking workplace incivility, Organizational Dynamics, 29, 123-37.

32. Pearson, C. and Porath, C. (2009), The Cost of Bad Behavior: How Incivility Ruins Your Business and What You Can Do about It, Portfolio, New York, NY.

33. Porath, C. (2015). The costs of bad behavior: And what leaders can do to manage it. Organizational Dynamics, 44, 254-257.

34. Porath, C., \& Pearson, C. (2013). The price of incivility. Harvard Business Review, 91, 114-121.

35. Porath, C. L., Gerbasi, A., \& Schorch, S. I. (2015). The effect of civility on advice, leadership, and performance. Journal of Applied Psychology, 100, 1527-1541

36. Porath, C. (2015). The costs of bad behavior: And what leaders can do to manage it. Organizational Dynamics, 44, 254-257.

37. Porath, C. L., \& Pearson, C. M. (2012). Emotional and behavioral responses to workplace incivility and the impact of hierarchical status. Journal of Applied Psychology, 42, 326357.

38. Rahim, A., \& Cosby, D. M. (2016). A model of workplace incivility, job burnout, turnover intentions, and job performance. Journal of Management Development, 35(10), 12551265

39. Rapp, A., Baker, T. L., Bachrach, D. G., Ogilvie, J., \& Beitelspacher, L. S. (2015). Perceived customer showrooming behavior and the effect on retail salesperson selfefficacy and performance. Journal of Retailing, 91(2), 358-369.

40. Reich, T.G. and Hershcovis, M.S. (2015), Observing workplace incivility and job performance, Journal of Applied Psychology, 100(1), 203-215.

41. Reio Jr, T. G., \& Ghosh, R. (2009). Antecedents and outcomes of workplace incivility: Implications for human resource development research and practice. Human Resource Development Quarterly, 20(3), 237-264.

42. Ringle, C. M., Sarstedt, M., \& Straub, D. (2012). A critical look at the use of PLS-SEM in MIS Quarterly.

43. Sarstedt, M., Ringle, C. M., Smith, D., Reams, R., \& Hair Jr, J. F. (2014). Partial least squares structural equation modeling (PLS-SEM): A useful tool for family business researchers. Journal of Family Business Strategy, 5(1), 105-115. 
44. Sharma, N., \& Singh, V. K. (2016). Effect of workplace incivility on job satisfaction and turnover intentions in India. South Asian Journal of Global Business Research, 5(2), 234249.

45. Seashore, S. E., Lawler, E. E., Mirvis, P., \& Cammann, C. (1982). Observing and measuring organizational change: A guide to field practice. New York, USA: Wiley.

46. Shaw, J. D., Duffy, M. K., Johnson, J. L., \& Lockhart, D. E. (2005). Turnover, social capital losses, and performance. Academy of Management Journal, 48, 594-606.

47. Van Waeyenberg, T., Decramer, A., \& Anseel, F. (2015). Home nurses' turnover intentions: the impact of informal supervisory feedback and self-efficacy. Journal of advanced nursing, 71(12), 2867-2878.

48. Wang, H., Hall, N. C., \& Rahimi, S. (2015). Self-efficacy and causal attributions in teachers: Effects on burnout, job satisfaction, illness, and quitting intentions. Teaching and Teacher Education, 47, 120-130.

49. Welbourne, J. L., Gangadharan, A., \& Sariol, A. M. (2015). Ethnicity and cultural values as predictors of the occurrence and impact of experienced workplace incivility. Journal of occupational health psychology, 20(2), 205.

50. Yeung, A., \& Griffin, B. (2008). Workplace incivility: Does it matter in Asia. People \& Strategy, 31(3), 14-9. 